\title{
How Do BANK CAPITAL AND CAPITAL ADEQUACY REGULATION AFFECT THE MONETARY TRANSMISSION MECHANISM?
}

\author{
MISA TANAKA \\ CESIFO WORKING PAPER NO. 799 \\ CATEgory 6: Monetary Policy and InTERnational FinANCE \\ OCTOBER 2002
}

Presented at Venice Summer Institute, July 2002

An electronic version of the paper may be downloaded

- from the SSRN website: www.SSRN.com

- from the CESifo website: www.CESifo.de 


\title{
HOW DO BANK CAPITAL AND CAPITAL ADEQUACY REgUlation AFFECT THE MONETARY TRANSMISSION MECHANISM?
}

\begin{abstract}
This paper analyzes the effect of bank capital adequacy regulation on the monetary transmission mechanism. Using a general equilibrium framework and a representative bank, the model demonstrates that the monetary transmission mechanism is weakened if banks are poorly capitalized, or if the capital adequacy requirement is stringent. The paper also assesses the impact of the New Basel Accord (Basel II), and argues that a rise in credit risk may lead to a sharper loan contraction under this new regime. Moreover, it predicts that Basel II may reduce the effectiveness of monetary policy as a tool for stimulating output during recessions.
\end{abstract}

JEL Classification: E5, G2.

\author{
Misa Tanaka \\ Nuffield College \\ University of Oxford \\ OXI INF \\ United Kingdom \\ misa.tanaka@nuffield.oxford.ac.uk
}

I am most grateful to my supervisors, Colin Mayer and Hyun Song Shin, for their support, discussions and comments. I would also like to thank Rui Fernandes, Gerhard Illing, Kohei Kawamura, Sophocles Mavroeidis, Kamakshya Trivedi and Yishay Yafeh for discussions and constructive criticism. Many thanks to the seminar participants at Oxford Said Business School and the Bank of England, and the participants in the Conference on EMU macroeconomic policies and institutions at University of Milan-Bicocca (September 2001), the Spring Meeting of Young Economists at the University of Paris 1 Panthéon-Sorbonne (April 2002) and CESifo Venice Summer Workshop (July 2002) for their feedback and constructive criticism. Financial support from Nuffield College is gratefully acknowledged. 


\section{Introduction}

The ongoing debate concerning the revision of the 1988 Basel Capital Accord the so called Basel I - has attracted much international attention and is being carefully followed by researchers, policy makers and the financial community. The proposed new Accord - Basel II - is likely to be implemented in 2006, and it is hoped that the revised Accord will enhance banks' incentives to control their risk exposure. Although it is widely believed that Basel II would promote financial stability, several concerns about its impact on macroeconomic stability have been voiced. In particular, the implications of the proposed regulatory change for banks' loan supply and the monetary transmission mechanism are not yet fully understood.

Since the introduction of Basel Capital Accord in 1988, several empirical papers have examined the link between bank capital and lending in different countries. Many of them have found evidence of "capital crunch", whereby banks subjected to capital adequacy requirement curtail their lending in response to a negative shock to their regulatory capital. In the American case, the analysis of cross-sectional, state-by-state data on bank loans by Bernanke and Lown (1991) reveals that banks' capital-to-asset ratio had a positive impact on loan growth during 1990-91, even after controlling for economic activity. Similarly, Peek and Rosengren (1995) find that for the period of 1989:I to 1992:II, banks in New England which were subjected to formal regulatory action curtailed their loans more sharply than those which were not. For the Japanese case, the panel data analysis of 85 banks for the period of 1990-92 by Ito and Nagataki Sasaki (1998) shows that the risk-based capital requirement constrained lending by internationally active banks which were subject to a more stringent capital adequacy regulation. ${ }^{2}$ Peek and Rosengren (1997) also report that a decline in the capital-to-asset ratio of Japanese parent banks led to a fall in lending by their American branches. More recently, Choi (2000) finds evidence that the recent imposition of $8 \%$ capital adequacy requirement on Korean banks has led to a decline in bank lending.

Given this accumulation of evidence on the impact of capital adequacy regulation, it is somewhat surprising that little progress has been made in developing a theoretical framework in which the macroeconomic implications of financial regulations can be assessed. Furthermore, the issue of how the capital adequacy requirement affects the monetary transmission mechanism has been largely ignored in the literature, despite the flourishing research which examines the role of the financial sector in the transmission of monetary policy. As a consequence, there exists no obvious model in which such policy issues surrounding the introduction of Basel II can be analyzed.

This paper is an attempt to fill this gap in the literature. Its primary objective is to examine the macroeconomic implications of the existing capital adequacy regulation (Basel I) and the proposed regulatory change (Basel II). In so doing, this paper will address two related, yet distinct issues concerning

\footnotetext{
${ }^{2}$ Japanese banks with international operations must maintain a capital-to-risk asset ratio of $8 \%$, while banks with domestic operations are required to maintain $4 \%$ only.
} 
the banking sector. First, using a microeconomic framework, it will determine the effect of capital adequacy regulation on banks' loan supply. Second, the paper will embed this microeconomic model into a general equilibrium framework, and analyze the role of the banking sector in the monetary transmission mechanism. A simple extension of this model will be used to highlight the potential macroeconomic side-effects of Basel II. In order to focus the analysis on the impact of Basel Accord on the monetary transmission mechanism, this paper will take the regulation as given. ${ }^{3}$

Currently, there are only a handful of papers which examine the effect of bank capital adequacy regulation on the monetary transmission mechanism using a formal framework. Blum and Hellwig (1995) analyzes the macroeconomic impact of capital adequacy regulation, but they do not consider its implications for monetary policy. This paper is perhaps most closely related to Bolton and Freixas (2000), Chami and Cosimano (2001) and Van den Heuvel (2002), which develop models of monetary transmission mechanism with a bank sector facing capital adequacy regulation. In all three papers, a contractionary monetary policy lowers the net interest margin and hence bank capital, which in turn reduces bank lending. In the static model developed by Bolton and Freixas (2000), a contractionary monetary policy reduces the net interest margin and hence the profitability of loans. This reduces banks' incentive to issue new equity to finance new loans, so that a monetary contraction constrains bank lending. On the other hand, bank lending is not affected by monetary policy if bank capital is fixed, since the level of lending is determined by the binding capital constraint. Similarly, in Chami and Cosimano (2001), monetary policy affects the banks' capacity to lend, by influencing their level of capital. If the loan market is imperfectly competitive, a monetary contraction reduces the net interest margin, so that it reduces the supply of future loans and the probability that the capital constraint will bind during the next quarter. Consequently, if banks are subject to a capital adequacy requirement, they will hold less equity this quarter and reduce lending next quarter. Using a dynamic model, Van den Heuvel (2002) argues that a contractionary monetary policy lowers bank profits by squeezing the net interest margin, and hence reduces bank capital which is assumed to be internally generated. Again, monetary policy affects bank lending through its impact on bank capital - a process which he calls "bank capital channel". Hence, all three papers focus on the effect of monetary policy on bank lending via its effect on bank capital.

In contrast to their approach, this paper focuses on the direct impact of monetary policy on bank loans through the conventional interest rate channel, and considers how the level of bank capital and the stringency of capital adequacy regulation affect the responsiveness of bank loans to changes in monetary policy. This paper will demonstrate that the level of bank capital and the stringency of capital adequacy regulation affect the interest elasticity of loan supply, which in turn determines the slope of the IS curve. Hence, the behaviour of

${ }^{3}$ For a welfare assessment of capital adequacy regulation, see inter alia Dewatripont and Tirole (1993) and Diamond and Rajan (2000). 
the banking sector determines the strength of the monetary transmission mechanism through the slope of the IS curve. This is in contrast to the theory of bank lending channel, which suggests that the IS curve shifts in response to a monetary shock, if bank loans play a special role in the economy. ${ }^{4}$

The rest of this paper is organized as follows. Section 2 will develop a stylized microeconomic model to analyze banks' optimal loan supply when they face capital adequacy regulation. In Section 3, this microeconomic model is embedded into a general equilibrium framework in order to examine the implications of capital adequacy regulation for the monetary transmission mechanism. Section 4 will then extend the model to analyze the potential impact of the New Basel Accord. Section 5 concludes.

\section{The Optimal Loan Supply}

This section will assess the impact of bank capital and capital adequacy regulation on lending, using a simple static model of a representative bank. Presently, banks with international operations are regulated by BIS capital adequacy regulation set out in the Basel Capital Accord, and they are required to maintain a minimum of $8 \%$ capital-to-risk-weighted-asset ratio, such that: ${ }^{5}$

$$
\frac{\text { capital }(=\text { Tier } I+\text { Tier } I I)}{\text { risk weighted assets }}>8 \%
$$

The capital regulation considered here is a simplified version of BIS capital adequacy regulation, given by (1). In the subsequent section, the microeconomic model developed here will be embedded in a general equilibrium framework, in order to analyze the implications for the monetary transmission mechanism.

\subsection{The Model}

Consider a simple two date model $(t=1,2)$ with a risk-neutral representative bank facing a competitive market. In this model, the bank collects deposits and invests in assets at date $t=1$. At date $t=2$, the return on all assets are realized, and the bank is audited by the regulator. The balance sheet of a representative bank at date $t=1$ can be described as follows:

\footnotetext{
${ }^{4}$ Elsewhere, I have argued that the theory of bank lending channel is based on mutually inconsistent assumptions. See Tanaka (2002a).

5 The numerator of this ratio, capital, is classified into Tier I and Tier II capital: The former consists of equity capital, while the latter consists of assets close to equity capital, such as subordinated debt. In many countries, capital gains or losses on bank assets - such as securities, land and real estate - are included as part of Tier II capital. Under the BIS capital regulation, banks are required to maintain at least $4 \%$ of Tier I capital-to-risk-weighted-asset ratio.
} 


$$
\begin{aligned}
& \text { Assets Liabilities } \\
& \text { res }=\text { reserves } \quad d=\text { deposits } \\
& l=\text { loans } \\
& b=\text { government bonds } \\
& c=\text { other assets } \quad k=\text { capital }
\end{aligned}
$$

Each bank holds only the minimum required reserves, res $=\tau d$, where $\tau$ is the required reserve ratio. At date $t=1$, the bank decides how to optimally allocate its deposits between loans and bonds, after taking aside the required reserves. The bank is assumed to invest all of its capital into a combination of other assets, $c$, so that $k=c$. Assume that the bank cannot raise additional capital at will, so that $k$ is assumed to be fixed in this model. Hence, the bank's balance sheet constraint is given by $l+b=(1-\tau) d$.

The bank faces capital adequacy requirement, $k_{0}\left(0 \leqslant k_{0} \leqslant 1\right)$, such that it will face a regulatory penalty, $V$, if its capital-to-risk asset ratio is found to be below the requirement at the time of audit $(t=2)$. The regulatory capital, $k^{R}$, which is the numerator of the capital-to-risk asset ratio, is a sum of the bank's equity capital, $k$, and the capital gains (or losses) on assets $c$, given by $\varepsilon$. $\varepsilon$ can be thought of as the component of Tier II capital - such as capital gains on securities, land and real estate held by banks - which fluctuates with market conditions. Here, we assume that, ex ante, $\varepsilon$ is independently and symmetrically distributed around a zero mean, so that the regulatory capital is given by:

$$
k^{R}=(1+\varepsilon) k \quad \text { where } \quad \varepsilon \sim \operatorname{iid}\left(0, \sigma^{2}\right)
$$

Assume further that the actual value of the capital gain (or loss) is realized at date $t=2$, so that $E_{t=1}\left(k^{R}\right)=k$. So the bank in this model chooses $d^{*}, l^{*}$, and $b^{*}$ in period $t=1$, before the actual value of the capital gain is realized at date $t=2$.

Since the bank is audited at date $t=2$, after $d^{*}, l^{*}$, and $b^{*}$ are chosen and the actual value of the capital gain or loss, $\varepsilon$, is realized, it will face a regulatory penalty $V$ if its capital-to-risk asset ratio is found to be below the requirement at the audit, i.e. if $\frac{k^{R}}{l}<k_{0}$. This "penalty condition" can also be expressed as:

$$
\frac{k_{0}}{\frac{k^{R}}{l}}=\frac{k_{0} l}{k^{R}}>1
$$

Note that $k_{0}=0$ signifies absence of capital adequacy regulation. Since $k^{R}$ has a random component, $\varepsilon$, there is, ex ante, always a positive probability, denoted as $q(0 \leqslant q \leqslant 1)$, that the bank will be penalized at date $t=2$. Given this set-up, the ex ante probability of facing a regulatory penalty, denoted as $q\left(\frac{k_{0} l}{k}\right)$, is a positive function of $\frac{k_{0} l}{E_{t=1}\left(k^{R}\right)}=\frac{k_{0} l}{k}$, where $q^{\prime}>0$. Assume further that the second derivative of $q$ is a positive constant $\left(q^{\prime \prime}>0, q^{\prime \prime \prime}=0\right)$. Note that $q^{\prime \prime}>0$ 
implies that the ex ante probability of facing a regulatory penalty increases at an accelerating rate as the bank's capital-to-asset ratio approaches the required ratio. ${ }^{6}$

The bank chooses its asset allocation and the deposit intake at date $t=1$ by maximizing its expected profit. Let $r^{L}$ and $r^{B}$ be the contractual return on loans, and the return on bonds. Furthermore, let $p$ be the ex ante probability of borrower default; and assume that in the event of a default by the borrower, the bank receives zero payoff in period $t=2 . \quad p$ can then be thought of as a proxy for aggregate credit risk, which is exogenously determined by business cycles. Let $r^{D}$ be the interest rate paid on deposits, and $r^{K}$ be the cost of capital, which is assumed to be fixed. The combination of assets, $c$, yields return $\rho$ which is a combination of a fixed return, $r^{C}$, and capital gain or loss, $\varepsilon$, which, ex ante, has zero mean. Hence, the actual return realized at date $t=2$ on the combination of these assets is $\rho=r^{C}+\varepsilon$, where $E_{t=1}(\rho)=r^{C}$. We expect that in a capital market equilibrium, $r^{C}=r^{K}$, so that capital yields zero returns on average. For notational simplicity, we denote the expected profit as $\pi\left(=E_{t=1}\left(\pi_{t=2}\right)\right)$.

Given this set-up, the bank's objective function at time $t=1$ can be written as:

$$
\operatorname{Max} \pi=(1-p) r^{L} l+r^{B} b+r^{C} c-r^{D} d-r^{K} k-q\left(\frac{k_{0} l}{k}\right) V
$$

$$
\text { s. t. } l+b=(1-\tau) d
$$

Since $r^{C} c=r^{K} k$, (2) can be simplified. Substituting the constraint (3) into (2), the above can be rewritten as:

$$
\operatorname{Max} \pi=(1-p) r^{L} l+r^{B}[(1-\tau) d-l]-r^{D} d-q\left(\frac{k_{0} l}{k}\right) V
$$

The profit-maximizing conditions are given by the following equations:

$$
\begin{aligned}
& \frac{\partial \pi}{\partial l}=r^{L}(1-p)-r^{B}-\left(\frac{k_{0}}{k}\right) q^{\prime} V=0 \\
& \frac{\partial \pi}{\partial d}=r^{B}(1-\tau)-r^{D}=0
\end{aligned}
$$

Hence, (5) gives the optimal level of loans. Assuming that the banking sector consists of $n$ identical banks, the equilibrium interest rate on deposits $r^{D *}$ satisfies (6), so that $r^{D *}$ is given by:

\footnotetext{
${ }^{6}$ Note that this assumption can be justified if $\varepsilon$ is not uniformly distributed, but its pdf is downward sloping to the left of its mean, $E(\varepsilon)=0$. For instance, if the distribution of $\varepsilon$ is symmetric and concentrated around the mean, this assumption is justifiable.
} 


$$
r^{D *}=r^{B}(1-\tau)
$$

Hence, banks issue deposits elastically at this given interest rate on deposits. The equilibrium quantity of deposits is determined by the money market equilibrium, which will be modelled subsequently in a general equilibrium framework.

\subsection{The Analysis}

\subsubsection{The Optimal Loan Supply}

The optimal portfolio $l^{*}$ solves the first order condition (5). Using the second order sufficient condition,

$$
\frac{\partial^{2} \pi}{\partial l^{2}}=-\left(\frac{k_{0}}{k}\right)^{2} q^{\prime \prime} V<0
$$

and noting that $q^{\prime}>0$ and $q^{\prime \prime}>0$ by assumption, the determinants of the bank's optimal loan supply are given by the following comparative statics results:

$$
\begin{aligned}
\frac{d l^{*}}{d k} & =\left(\frac{1}{k_{0}}\right)\left(\frac{q^{\prime}+\frac{k_{0} l}{k} q^{\prime \prime}}{q^{\prime \prime}}\right)>0 \\
\frac{d l^{*}}{d k_{0}} & =-\left(\frac{k}{k_{0}^{2}}\right)\left(\frac{q^{\prime}+\frac{k_{0} l}{k} q^{\prime \prime}}{q^{\prime \prime}}\right)<0 \\
\frac{d l^{*}}{d p} & =-\left(\frac{k}{k_{0}}\right)^{2} \frac{r^{L}}{q^{\prime \prime} V}<0 \\
\frac{d l^{*}}{d V} & =-\left(\frac{k}{k_{0}}\right) \frac{q^{\prime}}{q^{\prime \prime} V}<0 \\
\frac{d l^{*}}{d r^{L}} & =\left(\frac{k}{k_{0}}\right)^{2} \frac{(1-p)}{q^{\prime \prime} V}>0 \\
\frac{d l^{*}}{d r^{B}} & =-\left(\frac{k}{k_{0}}\right)^{2} \frac{1}{q^{\prime \prime} V}<0
\end{aligned}
$$

The results above clarify the determinants of banks' loan supply. (9) and (10) explain the empirically observed phenomenon of "capital crunch". A fall in capital or an increase in the capital adequacy requirement increases the probability of facing a regulatory penalty for any given level of loan supply. Hence, banks contract their loan supply, in order to reduce their risky asset holdings. Similarly, (12) is consistent with the empirical evidence given by Peek and Rosengren (1995). Since an increase in the severity of the penalty increases the cost of violating the regulation, the bank curtails its loans in order to reduce its risk asset. (11) shows that a rise in credit risk reduces banks' loan supply - an intuitive result. 
In the subsequent general equilibrium analysis of monetary transmission mechanism, the results (13) and (14) play an important role. As (14) illustrates, an increase in the bond rate makes loans less profitable relative to bonds, so that banks will try to hold less loans and more bonds. Hence, if banks' loan supply plays a role in determining the level of aggregate investment, the degree to which the monetary policy affects the output depends on the interest elasticity of loan supply with respect to $r^{B}$ and $r^{L}$.

\subsubsection{The Interest Elasticity of Loan Supply}

It can be shown that if banks face capital adequacy regulation, its stringency and the level of bank capital determine the interest elasticity of loan supply. Using the results obtained previously, it is straightforward to demonstrate that:

$$
\frac{\partial^{2} l^{*}}{\partial r^{B} \partial k}=\frac{\left(\frac{\partial^{3} \pi}{\partial^{2} l \partial k}\right)\left(\frac{d l^{*}}{d r^{B}}\right)}{-\left(\frac{\partial^{2} \pi}{\partial l^{2}}\right)}<0
$$

and

$$
\frac{\partial^{2} l^{*}}{\partial r^{L} \partial k}=\frac{\left(\frac{\partial^{3} \pi}{\partial^{2} l \partial k}\right)\left(\frac{d l^{*}}{d r^{L}}\right)}{-\left(\frac{\partial^{2} \pi}{\partial l^{2}}\right)}>0
$$

Using similar methods, it can also be shown that:

$$
\frac{\partial^{2} l^{*}}{\partial r^{B} \partial k_{0}}=\frac{\left(\frac{\partial^{3} \pi}{\partial^{2} l \partial k_{0}}\right)\left(\frac{d l^{*}}{d r^{B}}\right)}{-\left(\frac{\partial^{2} \pi}{\partial l^{2}}\right)}>0
$$

and

$$
\frac{\partial^{2} l^{*}}{\partial r^{L} \partial k_{0}}=\frac{\left(\frac{\partial^{3} \pi}{\partial^{2} l \partial k_{0}}\right)\left(\frac{d l^{*}}{d r^{L}}\right)}{-\left(\frac{\partial^{2} \pi}{\partial l^{2}}\right)}<0
$$

Proposition 1 A fall in bank capital or an increase in the capital adequacy requirement will make the optimal loan supply less sensitive to changes in the interest rates.

Proof. See Appendix.

Figure 1 illustrates this effect graphically. The intuition behind this result is simple. If banks' capital-to-asset ratio is very close to the required ratio, loans are insensitive to a fall in bond rate (or a rise in interest rate on loans), since banks do not have the ability to increase their risky asset holdings. Hence, a fall in bond rate (or a rise in interest rate on loans) will not lead to a significant increase in loans, because banks want to maintain their safe asset holdings so as not to violate the capital requirement. In the general equilibrium framework developed subsequently, the above results play an important role in illustrating how the conditions of the banking sector determine the slope of the IS curve, which in turn affects the strength of the monetary transmission mechanism. 


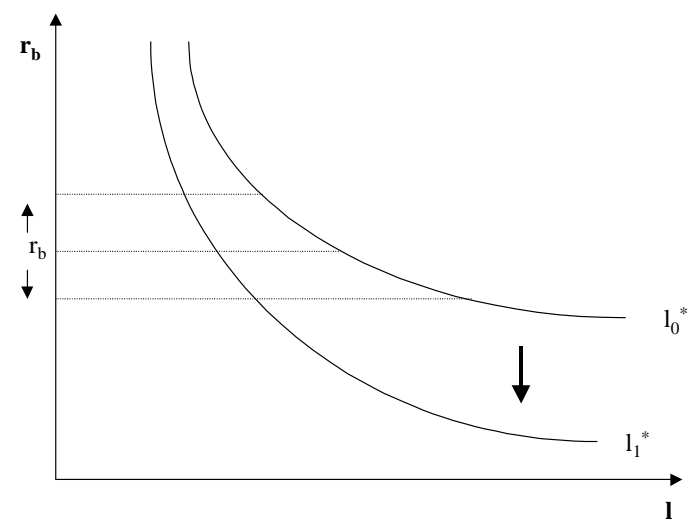

Figure 1: The effect of a fall in regulatory capital or an increase in required capital-to-asset ratio on loan supply $\left(\mathrm{l}, \mathrm{r}_{\mathrm{b}}\right)$

\section{The Monetary Transmission Mechanism}

This section will consider the effect of banks' behaviour on the monetary transmission mechanism, by making use of the results derived in the previous section. I will develop a general equilibrium model similar to that of Bernanke and Blinder (1988), in which the interest rate on loans affects aggregate investment. An important modification, however, is that the monetary transmission only operates through the usual interest rate channel. Monetary policy affects bank loans by altering the bond rate, which in turn affects the interest rate on loans - and not through changing the size of banks' portfolio for a fixed interest rate on bonds, as in Bernanke and Blinder (1988). ${ }^{7}$ Hence, in this model, there is no bank lending channel; instead, it will be shown that bank capital and capital adequacy regulation play a role in shaping the IS curve by affecting the interest elasticity of loan supply. Since the slope of the IS curve determines the magnitude of output change produced by a given shift in the LM curve, banks' behaviour has an important consequence on the effectiveness of monetary policy, even though it operates through the conventional interest rate channel only.

\subsection{The General Equilibrium Model}

Suppose that there are three assets in the economy - money (deposits), bonds and loans - so that the general equilibrium consists of equilibria in three markets:

\footnotetext{
${ }^{7}$ This modification is based on the criticism that the assumptions of their model are mutually inconsistent (Tanaka 2002a).
} 
the money market, the goods market and the loan market. ${ }^{8}$ Assume that there is no cash in the economy, so that the money supply consists of bank reserves, $R$, and the money demand consists of households' demand for deposits, $D(y$, $\delta$ ), where $y$ is the aggregate output, and $\delta$ is the spread between interest rates on bonds and deposits, $\delta=r^{B}-r^{D} .{ }^{9}$ Since the equilibrium interest rate on deposits is given by $(7), \delta^{*}=\tau r^{B}$. Assume that $\frac{\partial D}{\partial y}>0$ and $\frac{\partial D}{\partial r^{B}}<0$. Hence, the money market equilibrium condition can be described as:

$$
R=\tau D\left(y, \delta^{*}\right)=\tau D\left(y, \tau r^{B}\right)
$$

Equation (19) is the conventional LM curve, which determines $r^{B}$ and $D^{*}$ that clears the money market. An expansionary monetary policy reduces $r^{B}$ (and hence $\delta$ ) and increases deposits, as the money market equilibrium moves down along a fixed money demand curve. Hence, bank lending channel does not arise in this model, since (19) does not imply that the quantity of banks' loanable funds increases for any given $r^{B}$.

By totally differentiating (19) with respect to $r^{B}$, the slope of the LM curve can be obtained:

$$
\left(\frac{d y}{d r^{B}}\right)^{L M}=-\tau\left(\frac{\partial D^{*}}{\partial y}\right)^{-1} \frac{\partial D^{*}}{\partial r^{B}}
$$

$\left(\frac{d y}{d r^{B}}\right)^{L M}>0$, so that the LM curve is upward sloping.

The loan market equilibrium is given by

$$
L^{S}\left(r^{B}, r^{L}, p, K, k_{0}, V\right)=L^{D}\left(r^{B}, r^{L}\right)
$$

where $L^{S}$ and $L^{D}$ are the aggregate loan supply and loan demand, respectively. Assuming that the economy consists of $n$ identical banks $(i=1 \ldots n)$, the aggregate loan supply is given by the sum of $l_{i}^{*}, L^{S}()=.\sum_{1}^{n} l_{i}^{*}$, where $l_{i}^{*}$ solves (5) for bank $i$. Assume that the cost of non-bank finance available to firms depends on $r^{B}$, so that $\frac{\partial L^{D}}{\partial r^{B}}>0$ and $\frac{\partial L^{D}}{\partial r^{L}}<0$. Hence, (20) determines the market clearing level of loans and interest rate on loans, $r^{L *}$.

Finally, the goods market equilibrium is given by:

$$
I\left(r^{B}, r^{L *}\right)+G=S\left(y, r^{B}, r^{D}\right)
$$

where $I\left(r^{B}, r^{L *}\right)$ is the investment, $G$ is the government expenditure, and $S\left(y, r^{B}, r^{D}\right)$ is the savings, such that $\frac{\partial I}{\partial r^{B}}<0, \frac{\partial I}{\partial r^{L *}}<0, \frac{\partial S}{\partial y}>0, \frac{\partial S}{\partial r^{B}}>0$ and $\frac{\partial S}{\partial r^{D}}>0$. Note that unlike the conventional IS curve, $r^{L *}$ enters explicitly in the investment function. The implicit assumption here is that loans and bonds are imperfect substitutes in the firms' liabilities, so that bank loans play a special role in the economy. ${ }^{10}$

\footnotetext{
${ }^{8}$ Here, we will not consider the behaviour of capital markets; in effect, suppressing it by Walras' Law.

${ }^{9}$ Note that since there is no cash in the economy, the return on money is given by $r^{D}$, so that $\delta$ is the return on bonds relative to that on money.

${ }^{10}$ This assumption is consistent with the empirical evidence. See Gibson (1995), Hoshi et al. (1991), Hubbard et al. (2000) and Sekine (1999), inter alia.
} 
The slope of the IS curve can be obtained by totally differentiating (21) with respect to $r^{B}$ :

$$
\left(\frac{d y}{d r^{B}}\right)^{I S}=-\left(\frac{\partial S}{\partial y}\right)^{-1}\left[\frac{\partial S}{\partial r^{B}}+(1-\tau) \frac{\partial S}{\partial r^{D}}-\left(\frac{\partial I}{\partial r^{B}}+\frac{\partial I}{\partial r^{L *}} \frac{d r^{L *}}{d r^{B}}\right)\right]
$$

Hence, $\left(\frac{d y}{d r^{B}}\right)^{I S}<0$, so that we have a downward sloping IS curve. Unlike the conventional IS curve, its slope depends not only on $r^{B}$, but also on $r^{D}$ and $r^{L}$. This illustrates the assumptions implicit in the "money view", namely that bonds and deposits are perfect substitutes as a means of saving, and that loans and bonds are perfect substitutes in firms' liabilities. Also note that unlike the conventional IS curve, any shocks to the banking sector that changes the level of loan supply for any given $r^{B}$ will shift the IS curve. Examples of a positive shock to the banking sector that would shift out the IS curve include an increase in banks' equity capital, a relaxation of capital adequacy regulation, an exogenous fall in credit risk, and a mitigation in regulatory penalty - all of which have a positive effect on loan supply for any given $r^{B}$, as shown by the previous analysis in Section 2.

\subsection{The Impact of Capital Adequacy Regulation}

Equation (22) illustrates that the IS curve is flatter in the $\left(y, r^{B}\right)$ space when the term $\frac{\partial I}{\partial r^{L *}} \frac{d r^{L *}}{d r^{B}}$ is larger. The size of $\frac{\partial I}{\partial r^{L *}}$ depends on the substitutability of bank loans with other sources of finance for firms, so that the size of this term is small if firms can easily find an alternative source of funding when bank loans fall. The magnitude of $\frac{d r^{L *}}{d r^{B}}$, on the other hand, is determined by the elasticities of the demand and supply of bank loans. Using the results derived in the previous section, I will now examine the effect of banks' behaviour on the slope of the IS curve, which in turn determines the magnitude of output change produced by monetary policy. By totally differentiating (20) with respect to $r^{B}$, we can determine the sensitivity of the equilibrium loan rate $r^{L *}$ to changes in $r^{B}$ :

$$
\frac{d r^{L *}}{d r^{B}}=\frac{\frac{\partial L^{S}}{\partial r^{B}}-\frac{\partial L^{D}}{\partial r^{B}}}{\frac{\partial L^{D}}{\partial r^{L}}-\frac{\partial L^{S}}{\partial r^{L}}}>0
$$

Hence, an increase in the interest rate on bonds will increase the equilibrium interest rate on loans, since $\frac{\partial L^{S}}{\partial r^{B}}-\frac{\partial L^{D}}{\partial r^{B}}<0$ and $\frac{\partial L^{D}}{\partial r^{L}}-\frac{\partial L^{S}}{\partial r^{L}}<0$. (23) illustrates that the sensitivity of the equilibrium loan rate to changes in the bond rate depends on the interest elasticities of loan supply and loan demand. (22) and (23) reveal that if loans and bonds are perfect substitutes for firms $\left(\frac{\partial L^{D}}{\partial r^{L}}=-\infty\right.$, $\left.\frac{d r^{L *}}{d r^{B}}=0\right)$ or for banks $\left(\frac{\partial L^{S}}{\partial r^{L}}=\infty, \frac{d r^{L *}}{d r^{B}}=0\right)$, then the fluctuations in bank loans 
have no effect on the goods market equilibrium. Under such circumstances, (21) is reduced to the conventional IS in the "money only" framework.

So, how do the bank capital and capital adequacy regulation affect the monetary transmission mechanism? To answer this question, let $K$ be the total capital in the banking sector, $K=\sum_{1}^{n} k_{i}$. Using (15), (16) and (20), the following result can be shown:

$$
\frac{\partial^{2} r^{L *}}{\partial r^{B} \partial K}=\frac{\frac{\partial^{2} L^{S}}{\partial r^{L} \partial K} \frac{d r^{L *}}{d r^{B}}+\frac{\partial^{2} L^{S}}{\partial r^{B} \partial K}}{\frac{\partial L^{D}}{\partial r^{L}}-\frac{\partial L^{S}}{\partial r^{L}}}>0
$$

Similarly, using (17), (18) and (20):

$$
\frac{\partial^{2} r^{L *}}{\partial r^{B} \partial k_{0}}=\frac{\frac{\partial^{2} L^{S}}{\partial r^{L} \partial k_{0}} \frac{d r^{L *}}{d r^{B}}+\frac{\partial^{2} L^{S}}{\partial r^{B} \partial k_{0}}}{\frac{\partial L^{D}}{\partial r^{L}}-\frac{\partial L^{S}}{\partial r^{L}}}<0
$$

By combining these results with the expression (22), the following statement can be made:

Proposition 2 The IS curve is steeper in the $\left(y, r^{B}\right)$ space if the banking sector is poorly capitalized, or if the capital adequacy requirement is stringent, so that a given monetary shock will have a smaller impact on output.

Proof. See Appendix.

The intuition for this result can be explained as follows. If banks are severely under-capitalized (or face a stringent capital adequacy regulation), they will prefer to hold on to bonds and not increase loans, so as to not violate the capital adequacy requirement. Hence, loan supply becomes insensitive to a monetary expansion (i.e. the reduction in $r^{B}$ ). This explains why the conditions and regulations faced by the banking sector may affect the monetary transmission mechanism, even if there is no independent bank lending channel.

By combining the above results with the results derived in (9) and (10), the macroeconomic impact of bank capital and capital adequacy regulation can be summarized as follows:

Proposition 3 A fall in bank capital or an increase in the required capital adequacy ratio will both shift the IS curve to the left, and make the IS curve steeper in the $\left(y, r^{B}\right)$ space. Hence, ceteris paribus, equilibrium output will be lower and any subsequent monetary policy will be less effective.

Figure 2 presents a graphic illustration of this result. To sum up, this analysis shows why the conditions and regulations faced by the banking sector may have consequences both for the level of the real output, as well as the effectiveness of a monetary policy.

Note that unlike Bolton and Freixas (2000), Chami and Cosimano (2001) and Van den Heuvel (2002), the above analysis assumes that capital is fixed, so that it does not consider the impact of monetary policy on the level of bank capital. It is clear, however, that if a contractionary monetary policy reduces 


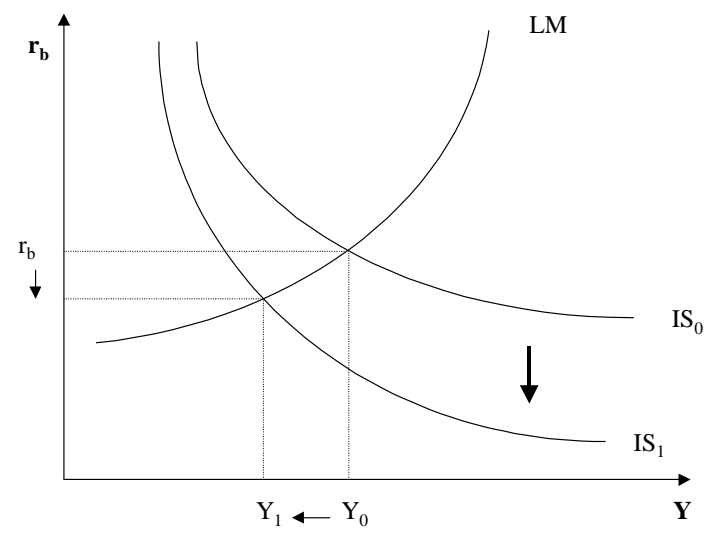

Figure 2: The effect of a fall in regulatory capital or an increase in required capital-to-asset ratio

bank capital, the effect described in Proposition 3 may also be generated by a monetary contraction. Suppose, à la Van den Heuvel (2002), that a contractionary monetary policy reduces bank profits at $t=0$, thereby lowering bank capital at $t=1$. If so, bank loans will contract at $t=1$, which in the aggregate will shift the IS curve to the left. Hence, if monetary policy has a direct effect on bank capital, a "bank capital channel" of monetary transmission might well arise (Van den Heuvel, 2002).

\section{The New Basel Accord (Basel II)}

Thus far, the analysis focused on the impact of the present BIS capital adequacy regulation on banks' loan supply. However, the Basel Committee on Banking Supervision is presently revising the regulations set out by the 1988 Accord, with the objective of developing more risk-sensitive standardized and internal measurement approaches to capital adequacy. One major proposal is to reform the minimum capital requirements by incorporating borrowers' credit risk in calculating the required ratio. In the present Accord, the risk-weight on loans (used to calculate the risk-weighted capital ratio) is determined by the category of borrowers only. For instance, all loans to the corporate or household sector receive a fixed $100 \%$ risk weight, regardless of the riskiness of a particular borrower. Under the proposed new Accord, on the other hand, the risk weight on loans is determined by both the category of borrowers and the riskiness of a particular borrower. Hence, instead of having a fixed $100 \%$ risk weight on 
all loans to the corporate sector, it is proposed that loans to corporates with sound credit rating receive $50 \%$ risk-weight, and those to corporates with poor rating are assigned 150\%. Since the amended Basel Capital Accord is likely to be implemented in year 2006, it would be useful to analyze the potential impact of the new Accord by extending this stylized model.

\subsection{The Effect of Credit Risk on Loan Supply}

The impact of Basel II can be analyzed using this framework by introducing a risk-weight variable that accounts for credit risk. Let $\alpha(p)$ be the risk-weight on loans which increases with the credit risk, such that $\alpha>0$ and $\alpha^{\prime}>0$. As before, the regulator penalizes the bank if its capital-to-risk asset ratio falls below $k_{0}$. In the new set-up, the bank will face a regulatory penalty if $\frac{k^{R}}{\alpha l}<k_{0}$ at the time of audit. Hence, in order to avoid the penalty, the bank must maintain:

$$
\frac{k_{0}}{\frac{k^{R}}{\alpha L}}=\frac{k_{0} \alpha l}{k^{R}}<1
$$

Note that the existing regulation can be described as: $\alpha=1$, and $\alpha^{\prime}=0$, which reduces the model to the one developed in the previous section. The probability of regulatory penalty at the time of audit can now be expressed as: $q\left(\frac{k_{0} \alpha l}{k}\right)$, where $q^{\prime}>0, q^{\prime \prime}>0$, and $q^{\prime \prime \prime}=0$. Assuming that the rest of the model remains unchanged, the bank's new objective function can be written as:

$$
\operatorname{Max} \pi^{N}=(1-p) r^{L} l+r^{B}[(1-\tau) d-l]-r^{D} d-q\left(\frac{k_{0} \alpha l}{k}\right) V
$$

The new profit-maximizing conditions are given by:

$$
\begin{aligned}
& \frac{\partial \pi^{N}}{\partial l}=r^{L}(1-p)-r^{B}-\left(\frac{\alpha k_{0}}{k}\right) q^{\prime} V=0 \\
& \frac{\partial \pi^{N}}{\partial d}=r^{B}(1-\tau)-r^{D}=0
\end{aligned}
$$

Since the primary objective of capital adequacy requirement is to promote safety and soundness of the financial system, it is important to assess how the new Accord will change the banks' risk-taking incentives. By totally differentiating (26) with respect to $p$, and using the second order condition $\frac{\partial^{2} \pi^{N}}{\partial l^{2}}=-\left(\frac{\alpha k_{0}}{k}\right)^{2} q^{\prime \prime} V<0$, obtain:

$$
\frac{d l^{*}}{d p}=\frac{-r^{L}-\left(\frac{k_{0}}{k}\right) \alpha^{\prime} V\left(q^{\prime}+\frac{k_{0} l}{k} q^{\prime \prime}\right)}{\left(\frac{\alpha k_{0}}{k}\right)^{2} q^{\prime \prime} V}<0
$$

Equation (27) allows us to analyze how the introduction of the new regulation affects the sensitivity of loans to changes in credit risk. In order to ensure comparability between the current regime (Basel I) and the new regime (Basel 
II), assume that $\alpha(\bar{p})=1$ under the new regime, where $\bar{p}$ is the mean probability of borrower default over business cycles. This assumption implies that on average, Basel II is neither more stringent $(\alpha(\bar{p})>1)$ nor less stringent $(\alpha(\bar{p})<$ 1) than Basel I. ${ }^{11}$

We analyze the benchmark case in which $p=\bar{p}^{12} \quad$ Under Basel I, $\alpha=1$ and $\alpha^{\prime}=0$, so that (27) becomes

$$
\left(\frac{d l^{*}}{d p}\right)^{\text {Basel I }}=\frac{-r^{L}}{\left(\frac{k_{0}}{k}\right)^{2} q^{\prime \prime} V}<0
$$

which is the same as (11). On the other hand, Basel II with $\alpha(\bar{p})=1$ and $\alpha^{\prime}>0$ implies that:

$$
\left(\frac{d l^{*}}{d p}\right)_{p=\bar{p}}^{\text {Basel II }}=\frac{-r^{L}}{\left(\frac{k_{0}}{k}\right)^{2} q^{\prime \prime} V}-\frac{\alpha^{\prime}\left(q^{\prime}+\frac{k_{0} L}{k} q^{\prime \prime}\right)}{\left(\frac{k_{0}}{k}\right) q^{\prime \prime}}<0
$$

Since $\frac{\alpha^{\prime}\left(q^{\prime}+\frac{k_{0} L}{k} q^{\prime \prime}\right)}{\left(\frac{k_{0}}{k}\right) q^{\prime \prime}}>0$, it is clear that:

$$
\left(\frac{d l^{*}}{d p}\right)_{p=\bar{p}}^{\text {Basel II }}<\left(\frac{d l^{*}}{d p}\right)^{\text {Basel I }}
$$

Proposition 4 For an average level of credit risk, Basel II will make banks' loan supply more sensitive to changes in credit risk; assuming that on average, the new capital adequacy requirement is neither more nor less stringent compared to the present requirement.

This result arises since under Basel II, a rise in credit risk will raise the probability of facing a regulatory penalty for given levels of capital and loans, in addition to reducing the expected return on loans. This restricts banks' ability to lend, and hence, a rise in credit risk will lead to a sharper loan contraction under the new Accord. ${ }^{13}$

The above analysis illustrates the potential cost and benefit of Basel II. On the one hand, the banking sector is likely to be safer, since its incentive to control the credit risk is stronger under the proposed new regulation. On the other hand, this result also implies that bank loans are likely to expand more rapidly during booms and fall more sharply during recessions, if the credit risk is determined by business cycles. Hence, if the credit risk is a function of business

\footnotetext{
${ }^{11}$ The Basel Committee on Banking Supervision explicitly states this as its objective in revising the Accord.

12 Note that this benchmark case ensures comparability between the current and the new Accord, since the level of optimal loan supply is the same under both regimes if $p=\bar{p}$.

${ }^{13}$ The weakness of this analysis is that it does not consider the possibility that banks may be able to allocate their loan portfolios between the two types of loans with different credit risks. However, this result (30) is likely to hold in general as long as there is aggregate credit risk affecting all borrowers via the business cycle, although the effect may be less pronounced if we introduce loans with different credit risks.
} 
cycles, the new regulation may exacerbate macroeconomic fluctuations. This issue is subject to active debate in the policy circles, although Basel Committee "believes that the benefits of a risk-sensitive capital framework outweigh this potential concern" (BIS 2001a).

\subsection{The Effect on the Interest Elasticity of Loan Supply}

Given that Basel II is likely to change banks' attitude towards risk, how does this change in capital regulation affect the interest elasticity of loan supply? This issue can be explored using a method similar to the one used in Section 2. By totally differentiating (26) with respect to $r_{t}^{B}$ :

$$
\left(\frac{\partial^{2} \pi^{N}}{\partial l^{2}}\right)\left(\frac{d l^{*}}{d r^{B}}\right)+\frac{\partial^{2} \pi^{N}}{\partial l \partial r^{B}}=0
$$

The comparative statics of the optimal loan supply with respect to the bond rate can be obtained from the above:

$$
\frac{d l^{*}}{d r^{B}}=\left(\frac{k}{\alpha k_{0}}\right)^{2} \frac{-1}{q^{\prime \prime} V}<0
$$

Using a similar method, it can be shown that

$$
\frac{d l^{*}}{d r^{L}}=\left(\frac{k}{\alpha k_{0}}\right)^{2} \frac{(1-p)}{q^{\prime \prime} V}>0
$$

Comparing (14) with (32), and (13) with (33), and assuming $\alpha(\bar{p})=1$, $\alpha(p<\bar{p})<1$, and $\alpha(p>\bar{p})>1$ as before, the impact of the new Accord can be summarized as follows:

$$
\begin{aligned}
& \text { If } p=\bar{p},\left(\frac{d l^{*}}{d r^{B}}\right)^{\text {Basel II }}=\left(\frac{d l^{*}}{d r^{B}}\right)^{\text {Basel I }} \text { and }\left(\frac{d l^{*}}{d r^{L}}\right)^{\text {Basel II }}=\left(\frac{d l^{*}}{d r^{L}}\right)^{\text {Basel I }} \\
& \text { If } p<\bar{p},\left(\frac{d l^{*}}{d r^{B}}\right)^{\text {Basel II }}<\left(\frac{d l^{*}}{d r^{B}}\right)^{\text {Basel I }} \text { and }\left(\frac{d l^{*}}{d r^{L}}\right)^{\text {Basel II }}>\left(\frac{d l^{*}}{d r^{L}}\right)^{\text {Basel I }} \\
& \text { If } p>\bar{p},\left(\frac{d l^{*}}{d r^{B}}\right)^{\text {Basel II }}>\left(\frac{d l^{*}}{d r^{B}}\right)^{\text {Basel I }} \text { and }\left(\frac{d l^{*}}{d r^{L}}\right)^{\text {Basel II }}<\left(\frac{d l^{*}}{d r^{L}}\right)^{\text {Basel I }}
\end{aligned}
$$

Hence, under Basel II, banks' loan supply responds more sensitively to changes in interest rates when the credit risk is low $(p<\bar{p})$. On the other hand, loan supply is less sensitive to changes in interest rates when the credit risk is high $(p>\bar{p})$.

In addition, credit risk plays an important role in determining the interest elasticity of loan supply under the new Basel Accord. Using (31), the following results can be obtained: 


$$
\frac{\partial^{2} l^{*}}{\partial r^{B} \partial p}=\frac{\left(\frac{\partial^{3} \pi^{N}}{\partial^{2} l \partial p}\right)\left(\frac{d l^{*}}{d r^{B}}\right)}{-\left(\frac{\partial^{2} \pi^{N}}{\partial l^{2}}\right)}=\frac{2 \alpha^{\prime}}{\alpha^{3}\left(\frac{k_{0}}{k}\right)^{2} q^{\prime \prime} V} \geq 0
$$

and

$$
\frac{\partial^{2} l^{*}}{\partial r^{L} \partial p}=\frac{\left(\frac{\partial^{3} \pi^{N}}{\partial^{2} l \partial p}\right)\left(\frac{d l^{*}}{d r^{L}}\right)}{-\left(\frac{\partial^{2} \pi^{N}}{\partial l^{2}}\right)}=\frac{-2 \alpha^{\prime}(1-p)}{\alpha^{3}\left(\frac{k_{0}}{k}\right)^{2} q^{\prime \prime} V} \leq 0
$$

Results (34) and (35) can be used to compare the interest elasticity of loan supply under the current regime with the proposed new regime. Under the present capital regulation $\alpha^{\prime}=0$, so that $\frac{\partial^{2} l^{*}}{\partial r^{B} \partial p}=\frac{\partial^{2} l^{*}}{\partial r^{L} \partial p}=0$. Hence, changes in credit risk will have no impact on the interest elasticity of loan supply under the current regime. Under the proposed new regime, on the other hand, $\alpha^{\prime}>0$, so that $\frac{\partial^{2} l^{*}}{\partial r^{B} \partial p}>0$ and $\frac{\partial^{2} l^{*}}{\partial r^{L} \partial p}<0$. This demonstrates that an increase in credit risk will make loans less sensitive to changes in interest rates under the proposed new regulation.

Proposition 5 Under Basel II, the optimal loan supply becomes less sensitive to changes in the interest rates when the credit risk is high.

Proof. See Appendix.

The intuition behind this is straightforward. Under the new Accord, the regulatory capital-to-asset ratio would be lower for any given level of capital and loans, if the credit risk is high. Since this constrains banks' ability to expand their risky asset holdings, loans become less sensitive to changes in interest rates.

\subsection{The Monetary Transmission Mechanism under Basel II}

The impact of the New Basel Accord on the monetary transmission mechanism has thus far received little attention both in the policy discussion and the academic literature. However, this regulatory change is likely to affect the transmission mechanism if it alters the interest elasticity of loan supply. Let $p$ be the credit risk faced by the banking sector. By employing a similar method to the one used above, it can be shown that under Basel II:

$$
\left(\frac{\partial^{2} r^{L *}}{\partial r^{B} \partial p}\right)^{\text {Basel II }}=\frac{\frac{\partial^{2} L^{S}}{\partial r^{L} \partial p} \frac{d r^{L *}}{d r^{B}}+\frac{\partial^{2} L^{S}}{\partial r^{B} \partial p}}{\frac{\partial L^{D}}{\partial r^{L}}-\frac{\partial L^{S}}{\partial r^{L}}}<0
$$

while under Basel I,

$$
\left(\frac{\partial^{2} r^{L *}}{\partial r^{B} \partial p}\right)^{\text {Basel I }}=\frac{\frac{\partial^{2} L^{S}}{\partial r^{L} \partial p} \frac{d r^{L *}}{d r^{B}}+\frac{\partial^{2} L^{S}}{\partial r^{B} \partial p}}{\frac{\partial L^{D}}{\partial r^{L}}-\frac{\partial L^{S}}{\partial r^{L}}}=0
$$


By combining these results with the expression (22), the following can be stated:

Proposition 6 Under the New Basel Accord, the IS curve is steep in $\left(y, r^{B}\right)$ space if the banking sector faces a high level of borrower credit risk, so that a given monetary shock will only have a small impact on output. Under the current Basel Accord, on the other hand, the borrower credit risk does not affect the slope of the IS curve.

Proof. See Appendix.

This analysis illustrates another potential cost of introducing the New Basel Accord, which is not widely recognized in the present policy discussion. The above result implies that under Basel II, an expansionary monetary policy may be less effective during recessions when credit risk tends to be higher; and conversely, it is likely to be more effective during a boom. This means that an expansionary monetary policy would be least useful when an economy needs the stimulus most! The intuition for this result is straightforward. Under Basel II, the regulatory capital-to-asset ratio would be lower for given levels of capital and loans if banks face a relatively high level of credit risk. Hence, loans are insensitive to an expansionary monetary policy (i.e. a fall in the bond rate), since banks do not have the ability to increase their risky asset holdings. This effect is absent under the current Accord since the capital-to-risk asset ratio is independent of credit risk.

By combining the above result with (30), the predicted impact of introducing the New Basel Accord can be summarized as follows:

Proposition 7 A given rise in borrower credit risk will lead to both a larger left-ward shift in the IS curve and to a steeper IS curve in the $\left(y, r^{B}\right)$ space after the introduction of the New Basel Accord. Hence, if there is a rise in credit risk, output contraction will be sharper and monetary policy will be less effective under Basel II than under Basel I.

Figures 3 illustrates this effect graphically.

\subsection{Discussion}

The above analysis suggests that while the proposed new Accord may be effective in reducing the riskiness of the banking sector, it might produce side-effects which are potentially undesirable from the perspective of macroeconomic stability. In particular, the analysis illustrates that when there is a general rise in credit risk - perhaps due to a macroeconomic downturn - loan supply contracts more sharply and the effectiveness of monetary policy is reduced under Basel II. This suggests that during a macroeconomic downturn, Basel II will help to preserve financial stability but may do so at the expense of macroeconomic stability. 

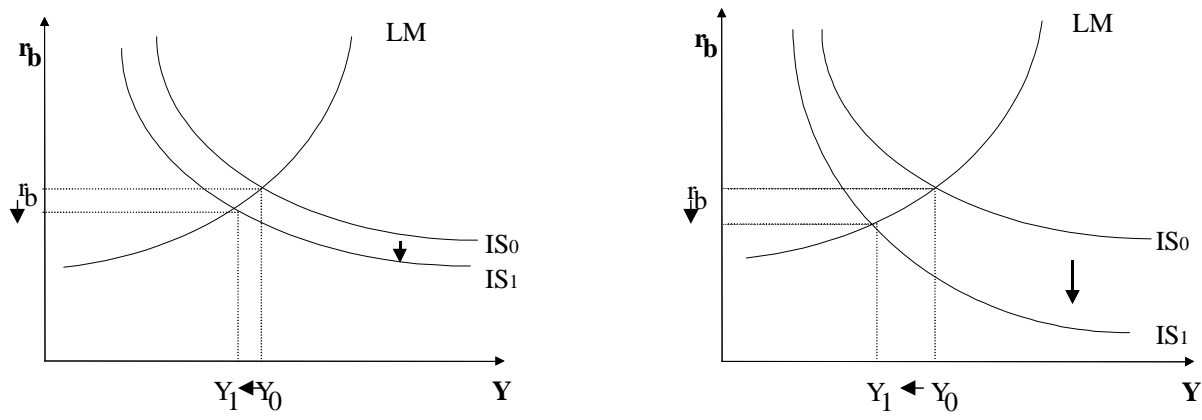

Figure 3: The effect of a rise in the credit under Basel I (left) and Basel II (right)

Note that this analysis assumes that banks face common exogenous risk - interpreted as macro credit risk - so that it does not consider the role of idiosyncratic risks. Arguably, the above effects may be mitigated, if banks can choose the level of their credit risk exposure. Instead of reducing their loan supply, banks may be able to shift their lending from riskier borrowers to safer ones if the rise in default risk affects only a particular class of borrowers. There are, however, two additional points to consider. First, the actual portfolio shift by banks may be limited if there is a price effect associated with the aggregate increase in loan supply to safer borrowers. If safer borrowers are able to bargain for lower rates, lending to these may become less attractive to individual banks. Second, the effects described in Proposition 7 are unlikely to disappear as long as there are some macroeconomic risk factors which affect a large segment of the banking sector. This is a reasonable and empirically valid assumption, especially if the banking sector is exposed to a common asset market. Evidence from Sweden and Japan in the 1990s show that the collapse of the real estate market - to which a majority of banks were heavily exposed to - was the origin of the banking problems in both countries. ${ }^{14}$ The theoretical analysis by Acharya (2001) also illustrates that banks may have the incentive to undertake correlated investments ex ante, if the surviving bank is likely to suffer large negative externalities from the failure of another bank ex post. His analysis implies that banks with correlated investments are likely to be affected by a common risk factor. Hence, macro risks are likely to be important, and the policy issues raised here are relevant concerns.

One way of mitigating the macroeconomic side-effects described in Proposition 7 is to give the financial regulators some discretion over the regulatory penalty imposed on a bank when it violates the capital adequacy regulation. It

${ }^{14}$ See Tanaka (2002b) for details. 
can be shown that the effects outlined in Proposition 7 can be eliminated if regulators can exercise "regulatory forbearance" - i.e. if they can reduce the penalty imposed on banks when they perceive a general macroeconomic downturn affecting the entire banking sector (see Appendix). Since the Basel Accord does not specify the sanctions for banks which fail to comply with its requirements, it is quite possible that governments may resort to regulatory forbearance in order to avoid a credit crunch during economic downturns. ${ }^{15}$ In principle, regulatory forbearance applied judiciously can be a useful tool for "coarse-tuning" the economy. On the other hand, forbearance may give rise to various types of inefficiencies, such as "gambling for resurrection", as the well-documented case of the American thrift crises demonstrates. Hence, the practical usefulness of regulatory forbearance as a tool for stimulating banks' loan supply during an economic downturn is not obvious.

More generally, an important implication of Proposition 7 is that central banks may have to adopt a much more aggressive monetary policy during recessions. A quick recapitalization of weak banks may also help restore the credit supply which in turn will stimulate output. Since the impact of Basel II on monetary transmission is likely to be felt most strongly by bank-based economies - such as Japan and Germany - the analytical results of this paper are especially relevant for policy makers of these countries.

\section{Conclusion}

This paper provides a general framework in which the macroeconomic impact of bank capital and capital adequacy regulation can be analyzed. The model illustrates that if bank loans play a special role in firms' liabilities, then the shocks affecting the level of loan supply for any given interest rate on bonds will shift the IS curve. In addition, the paper shows that bank capital and capital adequacy regulation are important determinants of the interest elasticity of loan supply, and hence the slope of the IS curve. Monetary policy is likely to be more effective if the banking sector is well-capitalized and the capital adequacy requirement is low, since the IS curve would be flatter. Moreover, a simple extension of the model predicts that Basel II reduces the effectiveness of monetary policy as a tool for stimulating output during recession.

The key insight of this paper is that the effectiveness of monetary policy may depend on the financial conditions and regulations faced by the banking sector. Hence, this model also has some important implications for empirical work examining the role of banks in monetary transmission mechanism. In particular, empirical studies relying solely on aggregate data or on firm level data may be of limited usefulness in illuminating banks' role in the monetary

\footnotetext{
${ }^{15}$ Japan, for instance, introduced some accounting changes at the height of its banking crises in order to help banks hide their losses. Specifically, the government introduced an accounting change in January 1998, allowing banks to value their stock and land holdings at book or market values. Most banks therefore used market values for land holding and book values for stock holdings to prop up their balance sheets. (Hoshi and Kashyap 1999).
} 
transmission mechanism when their financial conditions and/or regulatory environment have changed significantly during the study period. Indeed, this analysis may explain why empirical studies of the so-called "bank lending channel" have often produced conflicting results. ${ }^{16}$ In order to examine the degree to which banks affect monetary transmission mechanism, such studies should be complemented with an analysis of bank level data to control for bank-specific characteristics. ${ }^{17}$

One limitation of this paper is that it does not consider the possibility of imperfect information in the banking sector. In particular, the possibilities of moral hazard and "gambling for resurrection"-type behaviour may alter some of the results. Similarly, the dynamic macroeconomic impact of capital adequacy regulation cannot be analyzed within the static IS-LM framework used in this paper. While these are clearly important and empirically relevant issues, extensive consideration of these are outside the scope of this paper. An extension of the model incorporating imperfect information and dynamic analysis would be a fruitful possibility for future research.

\footnotetext{
${ }^{16}$ For empirical studies based on the US aggregate data, refer to inter alia Kashyap, Stein, and Wilcox (1993). For analysis of the US firm-level data, see, inter alia Oliner and Rudebusch (1995). While Kashyap et al found evidence of bank lending channel, Oliner and Rudebusch discovered no evidence on bank lending channel in the firm-level data.

${ }^{17}$ The recent work by Kashyap and Stein (2000) examines the role of banks in monetary transmission mechanism using bank level data. Their research demonstrates that the response of bank loans to changes in monetary policy depends on the liquidity of banks' balance sheet.
} 


\section{Appendix: Proofs}

\section{Proof. to Proposition 1}

By totally differentiating (5) with respect to $r^{B}$, obtain:

$$
\left(\frac{\partial^{2} \pi}{\partial l^{2}}\right)\left(\frac{d l^{*}}{d r^{B}}\right)+\frac{\partial^{2} \pi}{\partial l \partial r^{B}}=0
$$

Totally differentiate (38) with respect to $k$ :

$\left[\frac{\partial^{3} \pi}{\partial l^{3}}\left(\frac{d l^{*}}{d k}\right)+\frac{\partial^{3} \pi}{\partial^{2} l \partial k}\right]\left(\frac{d l^{*}}{d r^{B}}\right)+\frac{\partial^{2} \pi}{\partial l^{2}}\left(\frac{\partial^{2} l^{*}}{\partial r^{B} \partial k}\right)+\frac{\partial^{3} \pi}{\partial^{2} l \partial r^{B}}\left(\frac{d l^{*}}{d k}\right)+\frac{\partial^{3} \pi}{\partial l \partial r^{B} \partial k}=0$

We know that for $q^{\prime \prime \prime}=0, \frac{\partial^{3} \pi}{\partial l^{3}}=\frac{\partial^{3} \pi}{\partial^{2} l \partial r^{B}}=\frac{\partial^{3} \pi}{\partial l \partial r^{B} \partial k}=0$, and

$$
\left(\frac{\partial^{3} \pi}{\partial^{2} l \partial k}\right)=\frac{2 k_{0}}{k^{3}} q^{\prime \prime} V>0
$$

Since we know from (14) that $\frac{d l^{*}}{d r^{B}}<0$, and that $\frac{\partial^{2} \pi}{\partial l^{2}}<0$ by second order condition, we have:

$$
\frac{\partial^{2} l^{*}}{\partial r^{B} \partial k}=\frac{\left(\frac{\partial^{3} \pi}{\partial^{2} l \partial k}\right)\left(\frac{d l^{*}}{d r^{B}}\right)}{-\left(\frac{\partial^{2} \pi}{\partial l^{2}}\right)}<0
$$

The proof of (16) follows a similar method.

Similarly, by totally differentiating (38) with respect to $k_{0}$, obtain:

$$
\left[\frac{\partial^{3} \pi}{\partial l^{3}}\left(\frac{d l^{*}}{d k_{0}}\right)+\frac{\partial^{3} \pi}{\partial^{2} l \partial k_{0}}\right]\left(\frac{d l^{*}}{d r^{B}}\right)+\frac{\partial^{2} \pi}{\partial l^{2}}\left(\frac{\partial^{2} l^{*}}{\partial r^{B} \partial k_{0}}\right)+\frac{\partial^{3} \pi}{\partial^{2} l \partial r^{B}}\left(\frac{d l^{*}}{d k_{0}}\right)+\frac{\partial^{3} \pi}{\partial l \partial r^{B} \partial k_{0}}=0
$$

As before, we know that for $q^{\prime \prime \prime}=0, \frac{\partial^{3} \pi}{\partial L^{3}}=\frac{\partial^{3} \pi}{\partial^{2} L \partial r^{B}}=\frac{\partial^{3} \pi}{\partial L \partial r^{B} \partial k_{0}}=0$, and

$$
\left(\frac{\partial^{3} \pi}{\partial^{2} l \partial k}\right)=-\frac{2 k_{0}}{k^{2}} q^{\prime \prime} V<0
$$

Since we know from (14) that $\frac{d L^{*}}{d r^{B}}<0$, and that $\frac{\partial^{2} \pi}{\partial L^{2}}<0$ by second order condition, we have:

$$
\frac{\partial^{2} l^{*}}{\partial r^{B} \partial k_{0}}=\frac{\left(\frac{\partial^{3} \pi}{\partial^{2} l \partial k_{0}}\right)\left(\frac{d l^{*}}{d r^{B}}\right)}{-\left(\frac{\partial^{2} \pi}{\partial l^{2}}\right)}>0
$$

The proof of (18) follows a similar method.

\section{Proof. to Proposition 2}

By totally differentiating (20) with respect to $r^{B}$, obtain:

$$
\frac{\partial L^{D}}{\partial r^{L}} \frac{d r^{L *}}{d r^{B}}+\frac{\partial L^{D}}{\partial r^{B}}=\frac{\partial L^{S}}{\partial r^{L}} \frac{d r^{L *}}{d r^{B}}+\frac{\partial L^{S}}{\partial r^{B}}
$$


By totally differentiating (39) with respect to $K$, obtain:

$$
\frac{\partial L^{D}}{\partial r^{L}}\left(\frac{\partial^{2} r^{L *}}{\partial r^{B} \partial K}\right)=\frac{\partial^{2} L^{S}}{\partial r^{L} \partial K}\left(\frac{d r^{L *}}{d r^{B}}\right)+\frac{\partial L^{S}}{\partial r^{L}}\left(\frac{\partial^{2} r^{L *}}{\partial r^{B} \partial K}\right)+\frac{\partial^{2} L^{S}}{\partial r^{B} \partial K}
$$

so that

$$
\frac{\partial^{2} r^{L *}}{\partial r^{B} \partial K}=\frac{\frac{\partial^{2} L^{S}}{\partial r^{L} \partial K} \frac{d r^{L *}}{d r^{B}}+\frac{\partial^{2} L^{S}}{\partial r^{B} \partial K}}{\frac{\partial L^{D}}{\partial r^{L}}-\frac{\partial L^{S}}{\partial r^{L}}}
$$

where $\frac{\partial L^{D}}{\partial r^{L}}-\frac{\partial L^{S}}{\partial r^{L}}<0$. Using (15) and (16). the numerator can be re-written as:

$$
\frac{\partial^{2} L^{S}}{\partial r^{L} \partial K} \frac{d r^{L *}}{d r^{B}}+\frac{\partial^{2} L^{S}}{\partial r^{B} \partial K}=\frac{\frac{\partial^{3} \Pi}{\partial^{2} L^{S} \partial K}}{-\left(\frac{\partial^{2} \Pi}{\partial L^{S 2}}\right)}\left[\frac{\partial L^{S}}{\partial r^{L}} \frac{d r^{L *}}{d r^{B}}+\frac{\partial L^{S}}{\partial r^{B}}\right]
$$

where $\Pi$ is the total profit of the banking sector, $\Pi=\sum_{1}^{n} \pi_{i}$. Note that $\frac{\partial L^{S}}{\partial r^{L}} \frac{d r^{L *}}{d r^{B}}+\frac{\partial L^{S}}{\partial r^{B}}$ is simply the RHS of the expression (39). Since we know that LHS of (39) is negative, $\frac{\partial L^{S}}{\partial r^{L}} \frac{d r^{L *}}{d r^{B}}+\frac{\partial L^{S}}{\partial r^{B}}<0$. Since from the previous results, we know that $\frac{\partial^{3} \Pi}{\partial^{2} L^{S} \partial K}>0$ and $\frac{\partial^{2} \Pi}{\partial L^{S 2}}<0$ by second-order condition, the numerator of (24) is negative, so that $\frac{\partial^{2} r^{L *}}{\partial r^{B} \partial K}>0$.

The proof of (25) follows a similar method.

\section{Proof. to Proposition 5}

By totally differentiating (31) with respect to $p$, obtain:

$$
\left[\frac{\partial^{3} \pi^{N}}{\partial l^{3}}\left(\frac{d l^{*}}{d p}\right)+\frac{\partial^{3} \pi^{N}}{\partial^{2} l \partial p}\right]\left(\frac{d l^{*}}{d r^{B}}\right)+\frac{\partial^{2} \pi^{N}}{\partial l^{2}}\left(\frac{\partial^{2} l^{*}}{\partial r^{B} \partial p}\right)+\frac{\partial^{3} \pi^{N}}{\partial^{2} l \partial r^{B}}\left(\frac{d l^{*}}{d p}\right)+\frac{\partial^{3} \pi^{N}}{\partial l \partial r^{B} \partial p}=0
$$

For $q^{\prime \prime \prime}=0, \frac{\partial^{3} \pi^{N}}{\partial l^{3}}=\frac{\partial^{3} \pi^{N}}{\partial^{2} l \partial r^{B}}=\frac{\partial^{3} \pi^{N}}{\partial l \partial r^{B} \partial p}=0$, and

$$
\frac{\partial^{3} \pi^{N}}{\partial^{2} l \partial p}=-2\left(\frac{k_{0}}{k}\right)^{2} \alpha \alpha^{\prime} q^{\prime \prime} V<0
$$

Using (40) and (32), obtain:

$$
\frac{\partial^{2} l^{*}}{\partial r^{B} \partial p}=\frac{\left(\frac{\partial^{3} \pi^{N}}{\partial^{2} l \partial p}\right)\left(\frac{d l^{*}}{d r^{B}}\right)}{-\left(\frac{\partial^{2} \pi^{N}}{\partial l^{2}}\right)}=\frac{2 \alpha^{\prime}}{\alpha^{3}\left(\frac{k_{0}}{k}\right)^{2} q^{\prime \prime} V} \geq 0
$$

The proof for (35) follows a similar method.

\section{Proof. to Proposition 6}

Under the New Basel Accord, the loan supply is given by $L^{S}()=.\sum_{1}^{n} l_{i}^{*}$, where $l_{i}^{*}$ solves (26) instead of (5) for bank $i$. Using a method similar to the one used above, it can be shown that

$$
\frac{\partial^{2} r^{L *}}{\partial r^{B} \partial p}=\frac{\frac{\partial^{2} L^{S}}{\partial r^{L} \partial p} \frac{d r^{L *}}{d r^{B}}+\frac{\partial^{2} L^{S}}{\partial r^{B} \partial p}}{\frac{\partial L^{D}}{\partial r^{L}}-\frac{\partial L^{S}}{\partial r^{L}}}
$$


where $\frac{\partial L^{D}}{\partial r^{L}}-\frac{\partial L^{S}}{\partial r^{L}}<0$. From (34) and (35), we know that under the current Accord, $\frac{\partial^{2} L^{S}}{\partial r^{L} \partial p}=\frac{\partial^{2} L^{S}}{\partial r^{B} \partial p}=0$, so that $\left(\frac{\partial^{2} r^{L *}}{\partial r^{B} \partial p}\right)^{\text {Basel } I}=0$.

Under the new Accord, on the other hand, the numerator of the above expression can be re-written as:

$$
\frac{\partial^{2} L^{S}}{\partial r^{L} \partial p} \frac{d r^{L *}}{d r^{B}}+\frac{\partial^{2} L^{S}}{\partial r^{B} \partial p}=\frac{\frac{\partial^{3} \Pi^{N}}{\partial^{2} L^{S} \partial p}}{-\left(\frac{\partial^{2} \Pi^{N}}{\partial L^{S 2}}\right)}\left[\frac{\partial L^{S}}{\partial r^{L}} \frac{d r^{L *}}{d r^{B}}+\frac{\partial L^{S}}{\partial r^{B}}\right]>0
$$

where $\Pi^{N}$ is the total profit of the banking sector, $\Pi^{N}=\sum_{1}^{n} \pi_{i}^{N}$. As before, $\frac{\partial L^{S}}{\partial r^{L}} \frac{d r^{L *}}{d r^{B}}+\frac{\partial L^{S}}{\partial r^{B}}<0$. From (40), $\frac{\partial^{3} \Pi^{N}}{\partial^{2} L^{S} \partial p}<0$, and $\frac{\partial^{2} \Pi^{N}}{\partial L^{S 2}}<0$ by second order condition, so that the numerator of (31) is positive. Hence, $\left(\frac{\partial^{2} r^{L *}}{\partial r^{B} \partial p}\right)^{\text {Basel II }}<$ 0 .

\section{Proof. The Effect of Regulatory Forbearance}

It can be shown that the effects outlined in Proposition 7 can be eliminated if regulators can exercise "regulatory forbearance". To illustrate this, suppose that regulators can now adjust the size of regulatory penalty downward when there is a general rise in the credit risk. In the context of this model, this implies that the regulatory penalty parameter, $V$, is now a function of credit risk, $p$, such that $V^{\prime}(p)<0$. Using the same method as before, (29) can be rewritten as:

$$
\left(\frac{d l^{*}}{d p}\right)_{p=\bar{p}}^{\text {Basel II }}=\frac{\frac{\partial^{2} \pi^{N}}{\partial l \partial p}}{-\left(\frac{\partial^{2} \pi^{N}}{\partial l^{2}}\right)}=\frac{-r^{L}}{\left(\frac{k_{0}}{k}\right)^{2} q^{\prime \prime} V}-\frac{\alpha^{\prime}\left(q^{\prime}+\frac{k_{0} L}{k} q^{\prime \prime}\right)+q^{\prime} \frac{V^{\prime}}{V}}{\left(\frac{k_{0}}{k}\right) q^{\prime \prime}}
$$

This shows that the presence of regulatory forbearance reduces the sensitivity of loan supply to changes in credit risk.

Similarly, regulatory forbearance can mitigate the potentially undesirable impact of Basel II on the monetary transmission mechanism. (34) can be re-written as:

$$
\frac{\partial^{2} l^{*}}{\partial r^{B} \partial p}=\frac{\left(\frac{\partial^{3} \pi^{N}}{\partial^{2} l \partial p}\right)\left(\frac{d l^{*}}{d r^{B}}\right)}{-\left(\frac{\partial^{2} \pi^{N}}{\partial l^{2}}\right)}=\frac{2 \alpha^{\prime}+\alpha \frac{V^{\prime}}{V}}{\alpha^{3}\left(\frac{k_{0}}{k}\right)^{2} q^{\prime \prime} V}
$$

Hence, if the regulatory penalty is adjusted such that $\frac{V^{\prime}}{V}=-2 \frac{\alpha^{\prime}}{\alpha}, \frac{\partial^{2} l^{*}}{\partial r^{B} \partial p}=0$, the impact of Basel II on the monetary transmission mechanism outlined in Proposition 7 is effectively eliminated. 


\section{References}

[1] Acharya, V. (2001), "A Theory of Systemic Risk and Design of Prudential Bank Regulation", Working Paper, Stern School of Business, New York University.

[2] Bank of International Settlements (2001a). Consultative Document: Overview of The New Basel Capital Accord. Issued for comment by 31 May 2001. January 2001. Basel Committee on Banking Supervision.

[3] Bank of International Settlements (2001b). Consultative Document: The Standardised Approach to Credit Risk. Issued for comment by 31 May 2001. January 2001. Basel Committee on Banking Supervision.

[4] Bernanke, Ben S. \& Alan S. Blinder (1988). "Credit, Money and Aggregate Demand". American Economic Review, vol. 78, May 1988: 435-439.

[5] Bernanke, Ben S. \& Lown, Cara S. (1991). "The Credit Crunch". Brookings Papers on Economic Activity, vol. 0, no. 2: 204-239.

[6] Blum, Juerg \& Martin Hellwig (1995). "The Macroeconomic Implications of Capital Adequacy Requirements for Banks". European Economic Review, vol. 39: 735-749.

[7] Bolton, Patrick and Xavier Freixas (2000). "Corporate Finance and the Monetary Transmission Mechanism". mimeo, Universitat Pompeu Fabra.

[8] Chami, Ralph \& Cosimano, Thomas F. (2001). "Monetary Policy with a Touch of Basel". IMF Working Paper, WP/01/151.

[9] Choi, G. (2000). "The Macroeconomic Implications of Regulatory Capital Adequacy Requirements for Korean Banks". Economic Notes, vol. 29, no. 1 (February 2000): 111-43.

[10] Dewatripont, Mathias and Jean Tirole (1993). The Prudential Regulation of Banks. MIT Press.

[11] Diamond, Douglas W. (1991). "Monitoring and Reputation: The Choice between Bank Loans and Directly Placed Debt". Journal of Political Economy, vol. 99, no. 4: 689-721.

[12] Diamond, Douglas W. and Raghuram G. Rajan (2000). "A Theory of Bank Capital". Journal of Finance, vol. 55, issue 6: 2431-65

[13] Freixas, Xavier \& Rochet, Jean-Charles (1998) Microeconomics of Banking. MIT Press.

[14] Gibson, Michael (1995). "Can Bank Health Affect Investment? Evidence from Japan". Journal of Business, vol. 68, no.3: 281-308. 
[15] Hoshi, Takeo and Anil Kashyap (1999). "The Japanese Banking Crisis: Where did it come from and how did it end?". in Bernanke, Ben S. and Julio Rotemberg (eds), NBER Macroeconomic Annual 1999. MIT Press.

[16] Hoshi, Takeo, Anil Kashyap, and David Scharfstein (1991). "Corporate Structure, Liquidity, and Investment: Evidence from Japanese Industrial Groups". Quarterly Journal of Economics, vol. 106: 33-60.

[17] Hubbard, R. Glenn, Kenneth N. Kutter and Darius N. Palia (2000). Are there "Bank Effects" in Borrowers' Costs of Funds?: Evidence from a Matched Sample of Borrowers and Banks. http://www.gsb.columbia.edu/faculty/ghubbard/Papers.htm

[18] Ito, Takatsohi \& Yuri Natagaki Sasaki (1998). "Impacts of the Basle Capital Standard on Japanese Bank's Behavior". NBER Working Paper, \#6730.

[19] Kashyap, Anil K. \& Jeremy C. Stein (2000). "What Do a Million Banks Have to Say About the Transmission of Monetary Policy?". American Economic Review, vol. 90, no. 3: 407-428.

[20] Kashyap, Anil K., Jeremy Stein and David Wilcox (1993). "Monetary Policy and Credit Conditions: Evidence from the Composition of External Finance". American Economic Review, vol. 83, no. 1: 78-98.

[21] Oliner, Stephen D. \& Glenn, D. Rudebusch (1995). "Is There a Bank Lending Channel for Monetary Policy?". Federal Reserve Bank of San Francisco Economic Review. 1995, Number 2: 3-20.

[22] Peek, Joe \& Eric S. Rosengren (1997). "The International Transmission of Financial Shocks: The Case of Japan". American Economic Review, vol. 87, no. 4, September 1997: 495-505.

[23] Peek, Joe \& Eric Rosengren (1995). "Bank Regulation and the Credit Crunch". Journal of Banking and Finance, vol. 19: 679-692.

[24] Sekine, Toshitaka (1999). "Firm Investment and Balance-Sheet Problems in Japan". IMF Working Paper WP/99/111. International Monetary Fund, Policy Development and Review Department.

[25] Tanaka, Misa (2002a). "Does a Bank Lending Channel Exist?". mimeo.

[26] Tanaka, Misa (2002b). "Optimal Resolution of Failed Banks". mimeo.

[27] Van den Heuvel, Skander J. (2002). "The Bank Capital Channel of Monetary Policy". mimeo, University of Pennsylvania (Wharton School). 


\section{CESifo Working Paper Series}

(for full list see www.cesifo.de)

732 Yu-Fu Chen and Michael Funke, Working Time and Employment under Uncertainty, May 2002

733 Kjell Erik Lommerud, Odd Rune Straume, and Lars Sørgard, Downstream Merger with Oligopolistic Input Suppliers, May 2002

734 Saku Aura, Does the Balance of Power Within a Family Matter? The Case of the Retirement Equity Act, May 2002

735 Sandro Brusco and Fausto Panunzi, Reallocation of Corporate Resources and Managerial Incentives in Internal Capital Markets, May 2002

736 Stefan Napel and Mika Widgrén, Strategic Power Revisited, May 2002

737 Martin W. Cripps, Godfrey Keller, and Sven Rady, Strategic Experimentation: The Case of Poisson Bandits, May 2002

738 Pierre André Chiappori and Bernard Salanié, Testing Contract Theory: A Survey of Some Recent Work, June 2002

739 Robert J. Gary-Bobo and Sophie Larribeau, A Structural Econometric Model of Price Discrimination in the Mortgage Lending Industry, June 2002

740 Laurent Linnemer, When Backward Integration by a Dominant Firm Improves Welfare, June 2002

741 Gebhard Kirchgässner and Friedrich Schneider, On the Political Economy of Environmental Policy, June 2002

742 Christian Keuschnigg and Soren Bo Nielsen, Start-ups, Venture Capitalits, and the Capital Gains Tax, June 2002

743 Robert Fenge, Silke Uebelmesser, and Martin Werding, Second-best Properties of Implicit Social Security Taxes: Theory and Evidence, June 2002

744 Wendell Fleming and Jerome Stein, Stochastic Optimal Control, International Finance and Debt, June 2002

745 Gene M. Grossman, The Distribution of Talent and the Pattern and Consequences of International Trade, June 2002

746 Oleksiy Ivaschenko, Growth and Inequality: Evidence from Transitional Economies, June 2002

747 Burkhard Heer, Should Unemployment Benefits be Related to Previous Earnings?, July 2002 
748 Bas van Aarle, Giovanni Di Bartolomeo, Jacob Engwerda, and Joseph Plasmans, Staying Together or Breaking Apart: Policy-makers' Endogenous Coalitions Formation in the European Economic and Monetary Union, July 2002

749 Hans Gersbach, Democratic Mechanisms: Double Majority Rules and Flexible Agenda Costs, July 2002

750 Bruno S. Frey and Stephan Meier, Pro-Social Behavior, Reciprocity or Both?, July 2002

751 Jonas Agell and Helge Bennmarker, Wage Policy and Endogenous Wage Rigidity: A Representative View From the Inside, July 2002

752 Edward Castronova, On Virtual Economies, July 2002

753 Rebecca M. Blank, U.S. Welfare Reform: What's Relevant for Europe?, July 2002

754 Ruslan Lukach and Joseph Plasmans, Measuring Knowledge Spillovers Using Patent Citations: Evidence from the Belgian Firm's Data, July 2002

755 Aaron Tornell and Frank Westermann, Boom-Bust Cycles in Middle Income Countries: Facts and Explanation, July 2002

756 Jan K. Brueckner, Internalization of Airport Congestion: A Network Analysis, July 2002

757 Lawrence M. Kahn, The Impact of Wage-Setting Institutions on the Incidence of Public Employment in the OECD: 1960-98, July 2002

758 Sijbren Cnossen, Tax Policy in the European Union, August 2002

759 Chandima Mendis, External Shocks and Banking Crises in Developing Countries: Does the Exchange Rate Regime Matter?, August 2002

760 Bruno S. Frey and Lars P. Feld, Deterrence and Morale in Taxation: An Empirical Analysis, August 2002

761 Lars Calmfors and Åsa Johansson, Nominal Wage Flexibility, Wage Indexation and Monetary Union, August 2002

762 Alexander R. W. Robson and Stergios Skaperdas, Costly Enforcement of Property Rights and the Coase Theorem, August 2002

763 Horst Raff, Preferential Trade Agreements and Tax Competition for Foreign Direct Investment, August 2002

764 Alex Cukierman and V. Anton Muscatelli, Do Central Banks have Precautionary Demands for Expansions and for Price Stability? - Theory and Evidence, August 2002

765 Giovanni Peri, Knowledge Flows and Knowledge Externalities, August 2002

766 Daniel Friedman and Nirvikar Singh, Equilibrium Vengeance, August 2002 
767 Sam Bucovetsky and Michael Smart, The Efficiency Consequences of Local Revenue Equalization: Tax Competition and Tax Distortions, August 2002

768 Tapio Palokangas, International Labour Market Regulation and Economic Growth with Creative Destruction, August 2002

769 Rudi Dornbusch, The New International Architecture, September 2002

770 Hans-Werner Sinn, Weber's Law and the Biological Evolution of Risk Preferences: The Selective Dominance of the Logarithmic Utility Function, September 2002

771 Thomas Mayer, The Macroeconomic Loss Function: A Critical Note, September 2002

772 Seppo Honkapohja and Kaushik Mitra, Learning Stability in Economies with Heterogenous Agents, September 2002

773 David Laidler, Inflation Targets Versus International Monetary Integration - A Canadian Perspective, September 2002

774 Morten I. Lau, Panu Poutvaara, and Andreas Wagener, The Dynamic Cost of the Draft, September 2002

775 Steven Brakman, Harry Garretsen, and Charles van Marrewijk, Locational Competition and Agglomeration: The Role of Government Spending, September 2002

776 Anke S. Kessler and Christoph Lülfesmann, The Theory of Human Capital Revisited: On the Interaction of General and Specific Investments, September 2002

777 Kjell Erik Lommerud, Frode Meland and Lars Sørgard, Unionized Oligopoly, Trade Liberalization and Location Choice, September 2002

778 Antonio Merlo and François Ortalo-Magné, Bargaining over Residential Real Estate: Evidence from England, September 2002

$779 \mathrm{Yu}-\mathrm{Fu}$ Chen and Michael Funke, Exchange Rate Uncertainty and Labour Market Adjustment under Fixed and Flexible Exchange Rates, September 2002

780 Michael S. Michael, International Migration, Income Taxes and Transfers: A Welfare Analysis, September 2002

781 Clemens Fuest and Alfons Weichenrieder, Tax Competition and Profit Shifting: On the Relationship between Personal and Corporate Tax Rates, October 2002

782 Jan Bouckaert and Hans Degryse, Softening Competition by Enhancing Entry: An Example from the Banking Industry, October 2002

783 Johann K. Brunner and Susanne Pech, Adverse Selection in the Annuity Market with Sequential and Simultaneous Insurance Demand, October 2002

784 Gregory D. Hess and Eduard Pelz, The Economic Welfare Cost of Conflict: An Empirical Assessment, October 2002 
785 Jan Erik Askildsen, Uwe Jirjahn, and Stephen C. Smith, Works Councils and Environmental Investment: Theory and Evidence from German Panel Data, October 2002

786 Geir H. Bjønnes, Dagfinn Rime, and Haakon O. Aa. Solheim, Volume and Volatility in the FX-Market: Does it matter who you are?, October 2002

787 John Evans and John Fingleton, Entry Regulation and the Influence of an Incumbent Special Interest Group, October 2002

788 Wolfgang Ochel, International Comparisons and Transfer of Labour Market Institutions, October 2002

789 B. Gabriela Mundaca, Moral Hazard Effects of Bailing out under Asymmetric Information, October 2002

790 Gene M. Grossman and Edwin L.-C. Lai, International Protection of Intellectual Property, October 2002

791 John Hassler, José V. Rodriguez Mora, Kjetil Storesletten, and Fabrizio Zilibotti, A Positive Theory of Geographic Mobility and Social Insurance, October 2002

792 Paul De Grauwe and Marianna Grimaldi, The Exchange Rate in a Model with Heterogeneous Agents and Transactions Costs, October 2002

793 Guido Friebel and Mariassunta Giannetti, Fighting for Talent: Risk-shifting, Corporate Volatility, and Organizational Change, October 2002

794 Jan Erik Askildsen, Badi H. Baltagi, and Tor Helge Holmås, Will Increased Wages Reduce Shortage of Nurses? A Panel Data Analysis of Nurses' Labour Supply, October 2002

795 Marko Köthenbürger and Panu Poutvaara, Social Security Reform and Intergenerational Trade: Is there Scope for a Pareto-Improvement?, October 2002

796 Paul De Grauwe and Laura Rinaldi, A Model of the Card Payment System and the Interchange Fee, October 2002

797 Volker Böhm and Tomoo Kikuchi, Dynamics of Endogenous Business Cycles and Exchange Rate Volatility, October 2002

798 Mariam Camarero, Javier Ordóñez, and Cecilio Tamarit, The Euro-Dollar Exchange Rate: Is it Fundamental?, October 2002

799 Misa Tanaka, How Do Bank Capital and Capital Adequacy Regulation Affect the Monetary Transmission Mechanism?, October 2002 